\title{
AUTOPERCEPÇÃO DE HABILIDADES DE PLANEJAMENTO DOS EMPREENDEDORES: EVIDÊNCIAS DE EMPRESÁRIOS BRASILEIRO
}

\section{RESUMO}

Este estudo examinou se os empreendedores se vêem como planejadores estratégicos e procurou entender os fatoreschave que contribuem no desenvolvimento de seus negócios. Trata-se de uma pesquisa quantitativa-qualitativa. Participaram da pesquisa 339 empreendedores que estão à frente de seus negócios pelo menos há 5 anos em São Paulo, Brasil. Um questionário com 27 perguntas foi validado, contendo itens sobre planejamento, estratégia e empreendedorismo. Os dados foram analisados, inicialmente, por meio de análise fatorial que determinaram seis fatores denominados: ambiente externo, inovação, ambiente interno, experiência, missão e impulsividade. A parte qualitativa do estudo trouxe uma discussão sobre esses fatores. A relevância dos ambientes, interno e externo, é mostrada pela relação e importância que estes fatores podem exercer no desempenho da empresa, incluindo informações sobre as melhores práticas de mercado na produção de produtos/serviços, em comparação com forças e fraquezas internas. A incerteza e as variações do ambiente faz com que o esforço de planejar seja uma tarefa difícil para os empreendedores. Por outro lado, as habilidades pessoais, incluindo a sua capacidade inovadora, juntamente com a experiência acumulada podem compensar a falta de planejamento. Graças a essas qualidades, os empreendedores estão constantemente aprimorando suas habilidades para criar e gerenciar seus negócios e, ao longo do tempo, alcançar o sucesso. Os fatores em elevação, demonstrados na análise fatorial, indicam que as iniciativas dos empreendedores de fazer o planejamento estratégico se equilibram entre os fatores ambientais e habilidades pessoais. A abordagem teórica, effectuation $e$ causation, explica como os empreendedores lidam com este equilíbrio no momento de decidir, agindo impulsivamente ou planejando em certas condições, o que representa a contribuição fundamental deste artigo.

Palavras-chave: Empreendedor; Empreendedorismo; Planejamento; Estratégia.

\section{ENTREPRENEURS SELF-PERCEPTION OF PLANNING SKILLS: EVIDENCES FROM BRAZILIAN ENTREPRENEURS}

\begin{abstract}
This study examined whether entrepreneurs see themselves as good strategic planners and understand key factors that contribute to plan their business endeavors. This is a quantitative-qualitative research. 339 entrepreneurs ahead of businesses with at least 5 years of existence in Sao Paulo, Brazil answered a survey with 27 validated questions about planning, strategy and entrepreneurship. Data was analyzed through factorial analysis. Results showed six factors named external environment, innovation, internal environment, experience, mission and impulsiveness. The qualitative part of the study brought a discussion about these factors. The relevance of the internal and external environments is shown by the important relationship and influence that these may exercise in the performance of the enterprise, including information about best practices of the market in the production of products/services in comparison to internal strengths and weaknesses. In contrast to environmental uncertainty and variations, that makes the planning effort extremely difficult for entrepreneurs. We suggest that their personal abilities can compensate the lack of planning, including their innovative ability together with accumulated experience. Thanks to these qualities, entrepreneurs are constantly honing their abilities to create and manage their businesses and, over time, achieving success. The factors rose on the analysis shows that the strategic planning initiatives of entrepreneurs balance both environmental facts and personal abilities. The theoretical approach of effectuation and causation explains how entrepreneurs deal with this balance when deciding to act impulsively or planned in certain conditions, representing the key contribution of this article.
\end{abstract}

Keywords: Entrepreneur; Entrepreneurship; Planning; Strategy. 


\section{EMPRENDEDORES PERCEPCION DE LAS COMPETENCIAS DE PLANIFICACIÓN: Evidencias DE EMPRESARIOS DE BRASIL}

\section{RESUMEN}

El presente estudio examinó si los empresarios se ven como los planificadores estratégicos y trató de entender los factores clave que contribuyen en el desarrollo de sus negocios. Se trata de una investigación cuantitativa y cualitativa. 339 empresarios participaron en la encuesta que están por delante de su negocio por lo menos 5 años en São Paulo , Brasil. Un cuestionario con 27 preguntas fue validada, que contiene artículos sobre la planificación, la estrategia y el espíritu empresarial. Los datos se analizaron inicialmente utilizando análisis factorial determinó que seis factores denominados : ambiente externo, la innovación, el medio ambiente interno, la experiencia, la misión y la impulsividad - La parte cualitativa del estudio proporciona un análisis de estos factores. La relevancia de los entornos internos y externos se demuestra la relación y la importancia de estos factores puede tener en el rendimiento del negocio , incluyendo información sobre las mejores prácticas de mercado en la producción de productos / servicios , en comparación con las fortalezas y debilidades internas. La incertidumbre y los cambios en el medio ambiente hace que el esfuerzo de planear es una tarea de enormes proporciones para los empresarios. Por otra parte, las habilidades de las personas, incluyendo su capacidad de innovación, junto con la experiencia acumulada pueden compensar la falta de planificación. Gracias a estas cualidades, los empresarios están constantemente perfeccionando sus habilidades para crear y gestionar su negocio y, con el tiempo, alcanzar el éxito . Factores de altitud, que se muestra en el análisis factorial indican que las iniciativas de los empresarios para hacer la planificación estratégica se equilibran entre los factores ambientales y las habilidades personales. El enfoque teórico, efectivización y la causalidad, explica cómo los empresarios se ocupan de este equilibrio en la decisión, la planificación o actuar impulsivamente , bajo ciertas condiciones, que es la contribución fundamental de este trabajo.

Palabras-clave: Emprendedor; El Espíritu Empresarial; La Planificación; La Estrategia.

Vânia Maria Jorge Nassif ${ }^{1}$ Marcos Hashimoto ${ }^{2}$ Derly Jardim Amaral ${ }^{3}$

\footnotetext{
${ }^{1}$ Doutora em Administração de Empresas pela Universidade Presbiteriana Mackenzie. Professora do Programa de Mestrado Profissional em Administração - Gestão do Esporte da Universidade Nove de Julho - PMPA-GE/UNINOVE. Brasil. E-mail: vaniamjn@uninove.br

${ }^{2}$ Doutor em Administração de Empresas pela Fundação Getulio Vargas - FGV. Professor da Faculdade Campo Limpo Paulista - FACCAMP. Brasil. E-mail: hashi.marcos@gmail.com

3 Doutor em Administração pela Universidade Presbiteriana Mackenzie. Professor da Universidade Presbiteriana Mackenzie. Brasil. E-mail: djamaral@uol.com.br
} 


\section{INTRODUCTION}

The literature clearly shows that entrepreneurs are audacious and daring. However, according to Bhidé (2004), entrepreneurs do not face great risks. This author does affirm that they tolerate, as few others, living with uncertainty and ambiguity. On the other hand, Gartner (1988) points out that numerous characteristics mentioned by entrepreneurial studies are not sufficient to differentiate who is an entrepreneur. Another view on recognizing this social actor is proposed by Mckenzie et al. (2007), who mention that the identification of opportunities, the intentions of this actor, and the actor's entrepreneurial abilities are required for exploring this environment. One of these abilities is the skill to plan in advance the execution of competitive strategies. Performing good strategic choices differentiate great entrepreneurs as audacious at the same time helps him to face the risks of facing uncertain environments with a reasonable level of control, in opposition to those who, although with entrepreneurial skills, cannot take the best decisions on how to exploit opportunities.

With this in mind, it becomes necessary to rethink the role of strategy formulation in the entrepreneurial business development to achieve the remarkable results and innovation base outcomes. Therefore, there is a growing need to understand more deeply the process of formulating strategies by which some entrepreneurs manage their businesses. However, the little knowledge about how entrepreneurs formulate and use strategies makes it difficult to reach a consensus among academic researchers on the definition of the multiplicity of applications of these social actors regarding strategy formulation and execution.

This amplitude of concepts about the phenomenon is evidenced by Shane (2006). He defines entrepreneurship as an activity that involves the discovery, evaluation and exploitation of opportunities to introduce new products and services, and ways of organizing markets, processes and raw materials through an organization of efforts that did not exist before. However, the same entrepreneurship studies deserves greater attention when establishing the relations between the abilities to make choices among the variety of strategic choices existing in ambiguous and uncertain environmental conditions and the process to organize actions to exploit the corresponding opportunities. Brazilian companies emerge under the rich and dynamic economic environment, in a similar way as to other BRIC $^{4}$ economies. The business opportunities are rising in several industries and nascent entrepreneurs are more interested to quickly establish their companies to exploit these opportunities

\footnotetext{
${ }^{4}$ Brazil, Russia, India and China.
}

than to consistently initiate business operations under the administrative basic foundations.

Nevertheless, more and more entrepreneurs in Brazil are establishing their business considering current business administration practices, Wright et al. (2000) states the need to reflect, under the scientific context, their entrepreneurial actions under the administrative foundations. The nascent business discontinuity rate is decreasing in the last years (MIZUMOTO et al., 2010) and one of the reasons is the awareness of the entrepreneur to begin planning the business since its birth.

Therefore, it is important to understand whether business outcomes are reached through the analysis of internal and external environment, goals definitions, mission drives, acquired experience and other elements of business planning. The common aspects required from both large companies and small business in relation to strategic choices and their execution reinforces the idea that the relationship between entrepreneurship and planning is important, and through this relationship, perspectives for a better understanding of the phenomenon are opened.

This background has inspired the development of this study, considering that the literature has not reached concrete conclusion about the relation between entrepreneurs and planning so far. The key contribution of this study is to propose a reflection about the importance of the elements inherent to planning for entrepreneurs in managing their businesses. Thus, we intend to identify, through a quantitative-qualitative research, whether entrepreneurs use to adopt planning techniques in the conduction of their businesses and which categories of planning they apply most.

This article begins with a theoretical review of business planning and entrepreneurship. It then presents the methodological procedures and, finally, the results of the field research and the conclusions.

\section{ENTREPRENEURS AND INTREPRENEURSHIP}

The entrepreneurial phenomenon is not recent. Interest in this area has led social scientists to a significant increase of studies about the way entrepreneurs establish their decisions and actions (Antoncic; Hisrich, 2003). The growing interest around the theme has motivated studies to identify the necessity to relate the common characteristics of entrepreneurs to the elements that explains business growth and its role and impact in the society. This has raised a high number of studies targeting the collection of characteristics of this social actor.

This was the object of study of economists like Schumpeter (1949), one of the first to mention that entrepreneurship is the capacity to act on the opportunities, generating innovations that break eventual economic stability to permanently transform markets into a process he named destructive creation, 
and driving research efforts to understand the entrepreneurial activity influence on economic development. It was also the target of behaviorists, such as McClelland (1961), for whom people develop the necessity for personal realization, stimulated by models inspired on the action of some 'national heroes'.

Trying to identify explanations that put together both visions, Kirzner (1973) contributions stated that the entrepreneur is the one who creates a balance, finding a positive position in a chaotic environment, attentive to profitable opportunities, observing and identifying when the market signalize unmet demand. That was consistent with the vision of Hisrich and Peters (1986) who believe that entrepreneurship is the dynamic process of creating more wealth. According to them, wealth is created by individuals who assume the primary risks concerning assets, time, and commitment to the career, or who provide value for some product or service:

\begin{abstract}
"Entrepreneurship is the process of creating something new with value, dedicating the necessary time and effort, assuming the corresponding financial, psychological and social risks, and receiving the consequent compensation of economic and personal satisfaction and independence." (Hisrich and Peters, 1986 p. 29)
\end{abstract}

Further studies on entrepreneurship showed deep interest on innovations as a way to better create value. Filion (1991) was one of these who best found associations between entrepreneurship and innovation defining the entrepreneur as an innovator with some distinguished characteristics such as creativity, persistence, internality (the ability to ensure that one's desires are realized), leadership, initiative, flexibility, and the ability to maximize resource utilization.

Going further on this perspective, Venkataraman (1997) affirmed that entrepreneurship depends on the relationship between the existence of profitable opportunities and the presence of entrepreneurial individuals, as well as in the evaluation of sources of opportunities and in the relations of these individuals to the tripod of discovery, appreciation, and exploitation.

Entrepreneurship, therefore, is a dynamic concept, and the entrepreneur stands out or arises when new situations appear requiring decisions in terms of new courses of actions (SOUZA and GUIMARAES, 2005). Brazilian entrepreneurs are not much far from this concept. Nassif et al (2007) field study with owners of establishments in the food industry, characterized the Brazilian entrepreneur as:

... a person who makes things happen; who changes and transforms the reality; who assumes the challenge of having one's own business; who dares to dream and assume risks; is innovative; is concerned with the survival of the planet; seeks for sustainable growth; visualizes and takes advantage of opportunities; and regiments and controls resources and people (NASSIF et al, 2007, p. $6)$. 


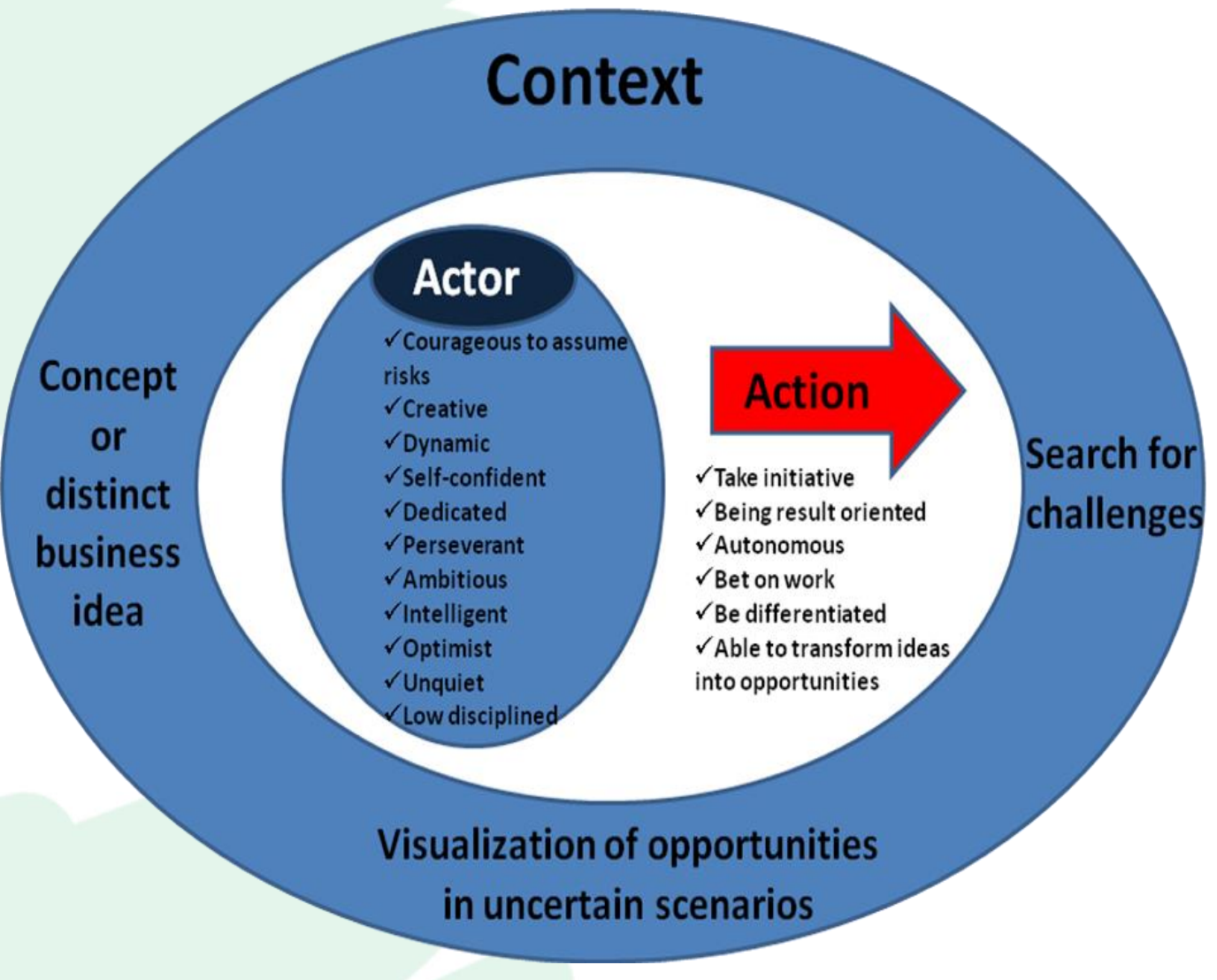

Figure 1 - Social Representation of the Entrepreneurial Concept

Source: Nassif, Cerretto, Amaral and Soares, 2007, p. 6

Figure 1 highlights the important characteristics of the Brazilian entrepreneur: visualizing, daring, transforming, and realizing. This suggests the capacity of the entrepreneur to achieve results through a process that sees the concretization of opportunities. The entrepreneur, from this viewpoint, can be understood as:

... a person of action. He/she is someone capable of realizing, transforming, visualizing opportunities, dreaming, believing, assuming risks and challenges, and aggregating resources and people. He/she is someone capable of inserting himself/herself actively in a context, seeking changes and innovations. Furthermore, he/she denotes a person capable of individual and professional realizations, overcoming challenges while seeking a way to make opportunities viable. (NASSIF et al, 2007, p. 7)

Despite the entrepreneurial individual characteristics, Mizumoto et al. (2010) have detected that one of the key reasons for business discontinuity is the lack of management practices, particularly planning and information seek skills. Therefore, to be an entrepreneur one must have much more than individual talent. More than planning, it is necessary to develop the capacity to invent and implant new procedures to achieve good results, detect new market needs, know how to meet them and evaluate opportunities costs.

It is a fact that theories, assumptions and actions adopted and developed inside companies are generated in both internal and external environment the same way some situations are handled according to entrepreneur's insights and experiences. Some of these decisions are eliminated and others are perpetuated through procedures and routines. Feuerschütte and Godoi (2007) punctuates that a complex problem, when observed through a hierarchic mental structure open the possibility to understand how entrepreneurs search for solutions and take decisions.

According Julien (2010), problems can be solved considering acquired experiences on past events or in those events which are daily repeated by the entrepreneur. Other problems, raised by uncertainty, involve the notion of risk, for which probability of occurrence is always variable (KURATKO; HODGETTS, 2008). The actions and decisions to deal with them depend on planning, action reviews, context evaluation, availability of data and information and verification of the current situation in order to take decisions that cannot be taken in a standalone perspective. There are several elements that can influence both the opportunities discovery and the 
finding of good problem/solution equation (SHANE; VENKATARAMAN, 2004). The adoption of planning techniques and/or strategies formulation can provide differentiated drive to the business.

\section{PLANNING, STRATEGY ENTREPRENEURIAL ACTIONS}

AND

It is true that strategies are relevant to developing business. The question in discussion is how entrepreneurs articulate or plan their strategies. To what degree do they use or ignore planned strategies in their business development? The ability to articulate a given strategy is related to the degree of maturity of the entrepreneur, his ability to conceive appropriate implementation approaches, and, above all, the current life-cycle status of the business (Bygrave; Hofer, 1991). As stated by Eisenhardt (1999), strategy is the process of decision-making for the company, strengthened by its collective intuition. Quinn (1980) points to strategy as a standard or plan that integrates objectives, goals, and policies, as well as a sequence of coherent actions with the company's structure and resources. Amplifying the concept, Jain (2000) considers strategy as a standard of policies and plans to achieve objectives and goals with the prospect of defining the type of business that the company is or desires to be.

It is worth to mention Wright et al (2000) strategy definition, not as corporate strategy, because it refers to the plans of top management to achieve results that are consonant with the mission and general objectives of the company, which, not necessarily attends the reality of small and nascent companies, but more relevant, is his view of strategy as the way to solicit the obtainment and allocation of human, organizational, and physical resources, facilitating strategic decisions upon people commitment oriented to the future.

An important characteristic of strategy is that it is based on the results of environmental analysis, on creating competitive advantage, and on being viable and compatible with the available resources. It is necessary that the strategies share coherence and seek the commitment of the people involved who are empowered to assume limited risks for the company for creative and innovative solutions, always based on the company's principles and values (PAGNONCELLI; VASCONCELLOS, 1992).

Strategy is usually linked to the understanding of the environment, a necessary step to the creation of sustainable competitive advantages opportunities and threats exploitation (DAFT et al., 1988; ABEBE et al., 2010; ANALOUI; KARAMI, 2002, 2006). The understanding of external environmental opportunities and threats is favored by the information obtained in the monitoring of the environment and fuels decisions to reinforce strategic choices or to suggest alternative courses of action, as well as exerts influence to the role of competencies for the orientation of the market, in view of the performance of its relationships (KUMAR et al., 2001, KARAMI et al., 2006, SUBRAMANIAN et al., 2009).

Therefore, strategic decisions involve preliminary actions that should guarantee their success. They deal with the analysis of strengths, weaknesses, opportunities, and threats for the survival of the enterprise. These analyses are primarily designed to aid in selecting the best strategy to be implemented by the organization from the study made of the internal and external environments (WRIGHT et al, 2000; SERRA et al., 2004).

According to Kuratko and Hodgetts (2008), "Strategic Planning is the formulation of long-range plans for the effective management of environmental opportunities and threats in light of a venture's strength and weaknesses, representing the primary step in determining the future direction of a business. It includes defining the venture's mission and specifying achievable objectives. The authors also suggest that the 'best' strategic plan is influenced by the abilities of the entrepreneur" (p.520). The following model illustrates how these variables are related to the strategic orientation of the company (Figure2): 


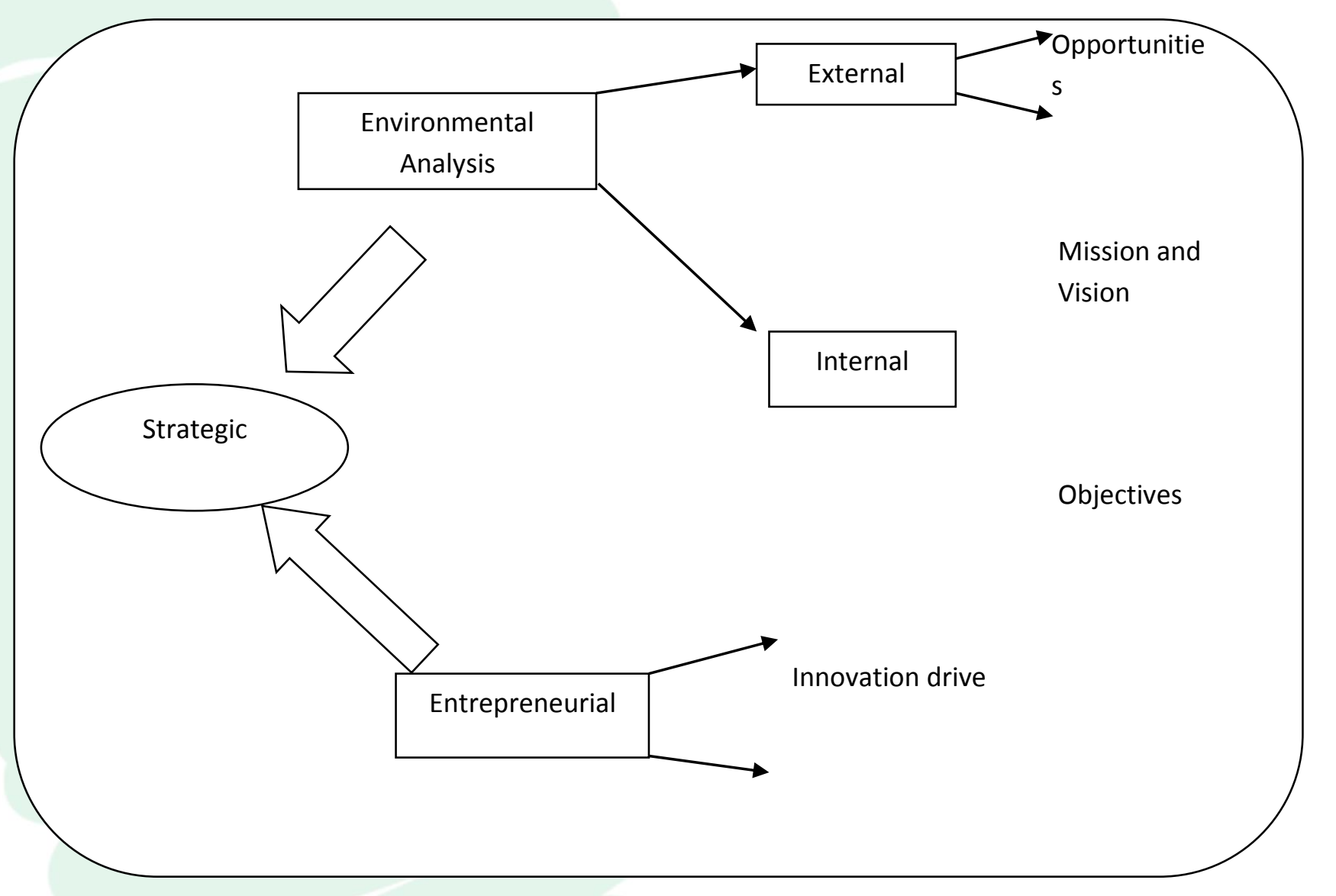

Figure 2- Strategic planning model of variables relationship Source: developed by the authors

According to Machado-da-Silva and Cochia (2003), the choices may be related to judgment made by directors concerning environmental pressures, and how these choices affect the strategies of actions in terms of reach and opportunity.

The same way, the key entrepreneurial characteristics of the company is combined to the internal and external environment as they exert deep influence on how the variables are handled for strategic decisions. Both entrepreneurial characteristics and environmental analysis will be discussed next.

\section{ANALYSIS OF THE EXTERNAL ENVIRONMENT}

According to Wright et al (2000), the external environment is formed by 'the conjunct of strengths of the macro-environment with the environment of the industry in which the company operates. These influence the strategic decision-making of the organization.' (p.47) The variables for the external environment are outside the organization and, in general, outside the short-term control of the top management.
According to Serra et al. (2004), the intention of the strategist in analyzing the external environment is to observe the possible threats in the operating environment and take advantage of potential opportunities provided by the market. The forces of the macro-environment may be classified as politicojudicial, economic, technological, and social - all exercising a significant impact on the enterprise (WRIGHT et al, 2000). Added to these forces are the demographic, cultural, consumer habit and opinion phenomena, which must be analyzed by the company in relation to society (SERRA et al. 2004).

The strategist perceives the threat of possible entrants in the industry and combats them with obstacles or entrance barriers that reduce the ingress of new potential competition in the sector (WRIGHT et al, 2000). The threat of substitute products or services is another important factor as its identification allows the administrator to adopt a better strategy to differentiate and value the product or service for the end consumer (SERRA et al. 2004).

Wright et al. (2000) states that suppliers have negotiating power if they dominate a large part of the market, if their products are differentiated, or if the client is not important to suppliers. Purchasers with high negotiating power are those that purchase in large 
scale with standardized and non-differentiated products that may be manufactured by the self-same purchasers or when the profits of the sector are reduced (SERRA, et al. 2004). A good strategist must be attentive to the number of suppliers, the important purchasers, and how important are them to the organization (PORTER, 2004).

\section{ANALYSIS OF THE INTERNAL ENVIRONMENT}

Through analysis of the internal environment of an organization, one can examine the possible strengths and weaknesses it has and where its resources (both tangible and intangible), capacities, and competencies are directed. Factors such as mission, vision, and company objectives are of great importance to the orientation of the strategist in relation to the market and its probable competition (HITT et al, 2005; WRIGHT et al, 2000).

Critical sense becomes the fundamental role of the entrepreneur in the verification, analysis, and accounting of information and variables directly linked to strategic decisions. The systemic interdependence of the external and internal factors influences decisions. Those identified in strategic diagnosis must result in a chain that operationalizes the analysis of all existing interconnections (OLIVEIRA, 1991).

Uncertainty is part of the decision. By working with the best of all possibilities and having a profound study, one can increase the chances of a positive result, though it cannot be guaranteed. Risk is a result of uncertainty; there is no strategy without risk, but risks can be calculated and minimized (OLIVEIRA, 1991).

It is important to cite that, primarily in the medium- and long-term strategies, in the course of actions, it is necessary to be attentive to change, be ready to adapt and readjust strategies, and create new action plans, when necessary, as new situations may arise.

\section{ENTREPRENEURIAL ABILITIES}

In order to raise the entrepreneurial spirit and for this to become a strategy of the enterprise, both in seeking innovation and in solutions, certain characteristics are perceived as a common base in entrepreneurial companies.

Creativity is part of the evaluation and suggestion at the decision-making time. It is necessary to remain attentive to the current changes in the market for possible adjustments, corrections, and improvements. In addition, it is necessary that the entrepreneur have initiative and coherence to make strategic decisions. It is the initiatives that open new routes and possibilities, taking the company forward (OLIVEIRA, 1991).

This same author states that after the analysis of these variables, the decision maker is apt to create scenarios to help track the objectives and goals of the company, such as the action plans. These analyses are advisable because they give a foundation to the various areas of the enterprise and provide security and support to decisions in the short-, medium-, and long-term.

Under the view of the theoretical approach, the entrepreneurial characteristics show a high level of alignment to a strategic planning in the conduction of the business.

\section{SURVEY DEVELOPMENT}

This study followed the parameters of the quantitative-qualitative method. The survey was conceived in two distinct phases. The first phase was to validate the survey content, constructed in three sessions: 1) presentation of study objectives and interests; 2) concepts of strategy and entrepreneurship adopted; 3) assertions developed for the specific study objectives and the second phase was to develop the final form of the survey. The development of the forty seven assertions came from the theoretical references previously presented and discussed, related to "strategy" and "entrepreneurship" themes. These assertions were randomly arranged in two columns indicating whether the assertions were related to the concept of strategy or entrepreneurship. The first was labeled as Option 01, and the second as Option 02.

Next, seven university professors from related areas, those who were available to participate in the content validation, were asked to carefully analyze each assertion and determine their classification as Option 01 (strategic planning) or Option 02 (entrepreneurship). The intention of the researchers was to guarantee that the assertions truly contemplated the concepts conceived for strategic planning and entrepreneurship, as well as to avoid problems of misinterpretation, misunderstanding or any other dilemma prior to the final application of the survey.

With the data collected from this phase, the researchers identified which assertions concentrated the most votes by the professors in a determined concept, either "strategic planning" or "entrepreneurship". Of the forty-seven initial assertions, twenty-eight were maintained as having achieved unanimity or quasiunanimity among the respondents, with fourteen related to "strategic planning" and fourteen related to "entrepreneurship".

With the content validated, phase two development of the final format of the survey - began. This survey was composed as follows: 1) Presentation of the study objectives and relevant information, so that respondents could properly understand and participate; 2) Demographic information, such as gender, age, size 
of enterprise and education; 3) the twenty-eight final assertions remained from the previous phase. These assertions were ordered in such a way as to prevent respondents from drawing associations among them. The survey utilized a 5 points Likert scale, varying from "completely agree" to "completely disagree". The survey was primarily given personally by the researchers, though in some cases electronically.

Brazil has a population around 200 million people, being $16,7 \%$ of entrepreneurs, according to Global Entrepreneurship Monitor Annual Report (2012), representing the largest participation of entrepreneurs since the research started being done in Brazil in 2000. A possible reason for such growth is a greater acceptability of overall population about the entrepreneurial career and the increasing unemployment rate along 2009.

The sample was mapped through a database owned and provided by FIESP (Sao Paulo State Manufacturers Federation) containing companies installed in Sao Paulo State in Brazil. The criteria to select the sample group were: a) to be active for, at least, five years; b) No matter the number of employees, the revenue was maximum US\$ 500K. c) companies managed by the founder entrepreneur. Data collection occurred in two ways: in person, from 87 entrepreneurs; and electronically, through 1276 emails sent, and the return of 252 valid answers. Total was 339 respondents. The data was collected between July and November of 2009.

Most of the entrepreneurs in this sample were men $(84.6 \%)$. Their age groups were equally distributed; no age group stood out from the rest. It should be emphasized that approximately $1 / 3$ of the sample was under 35 years old $(32.7 \%)$, which could demonstrate a tendency of young people toward entrepreneurship.

To define enterprise size, the researchers proposed the following classifications: revenue up to $\mathrm{R} \$ 1$ million per month = small size; between $\mathrm{R} \$ 1$ million and $\mathrm{R} \$ 3$ million = medium size; and over $\mathrm{R} \$ 3$ million = large size. The demographic data from the sample studied showed a concentration of enterprises characterized as small size $(69.2 \%)$, which could be explained by the facility and accessibility in data collection with entrepreneurs who operate in this revenue group.

Most of the entrepreneurs studied had a high level of schooling: post-graduate with $32.7 \%$ and university with $30.8 \%$. From the remaining, $23.1 \%$ held high school diplomas, and $11.5 \%$ held only elementary school certifications. Only $1.9 \%$ of those interviewed held doctorate level degrees. This information could indicate that most entrepreneurs of small size enterprises have between high school and post-graduate education levels.

The data collected were submitted to Factorial Analysis, observing the criteria proposed by Hair et al. (2006). The KMO (Kaiser-Meyer-Olkin) value, at 0.715, was considered appropriate, and Bartlett's spherical test showed a significance level of less than or equal to 0.000 , which indicated a highly elevated degree of confidence. Then an analysis of common variables was undertaken. Those presenting commonality less than 0.50 were withdrawn, which allowed the researchers to exclude nine variables. The rotational method, which Hair et al. (2006) call equimax, for its principal axes, was then utilized. With this rotation, six factors were obtained that explained $77 \%$ of the total explained variance. These procedures represent the quantitative part of the analysis.

\section{ANALYSIS AND INTERPRETATION OF THE DATA}

The qualitative part of the study follows below with a discussion of the data obtained from the Factor Analysis, as shown in Table 1. 
Table 1 - Factor Loads

\begin{tabular}{|c|c|c|c|c|c|c|}
\hline \multicolumn{7}{|c|}{ STANDARD MATRIX } \\
\hline & \multicolumn{6}{|c|}{ FACTOR } \\
\hline & $\begin{array}{c}\text { External } \\
\text { Environment }\end{array}$ & Innovation & $\begin{array}{c}\text { Internal } \\
\text { Environment }\end{array}$ & Experience & Mission & Impulsiveness \\
\hline Image of the Enterprise & 0.716 & & & & & \\
\hline Analysis of the Competition & 0.705 & & & & & \\
\hline Substitute Products \& Services & 0.670 & & & & & \\
\hline Taking Initiative & 0.624 & & & & & \\
\hline $\begin{array}{l}\text { New Ideas for a Competitive } \\
\text { Differential }\end{array}$ & & 0.707 & & & & \\
\hline $\begin{array}{l}\text { Innovative Solutions for } \\
\text { Unforeseen Situations }\end{array}$ & & 0.648 & & & & \\
\hline $\begin{array}{l}\text { Being Innovative as a Personal } \\
\text { Characteristic }\end{array}$ & & 0.620 & & & & \\
\hline Love of Risks and Challenges & & 0.584 & & & & \\
\hline Performance Indicators & & & -0.937 & & & \\
\hline Internal Economic Factors & & & -0.728 & & & \\
\hline Resource Organization & & & -0.369 & & & \\
\hline Previous Knowledge & & & & 0.822 & & \\
\hline Experience & & & & 0.809 & & \\
\hline Mission of the Enterprise & & & & & 0.954 & \\
\hline $\begin{array}{l}\text { Judicial and Governmental } \\
\text { Knowledge }\end{array}$ & & & & & 0.630 & \\
\hline Being Impulsive & & & & & & 0.825 \\
\hline Detailed Planning & - & 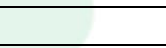 & & & & -0.572 \\
\hline Future Planning & & 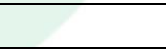 & & & & -0.505 \\
\hline Employee Commitment & & & & & & -0.352 \\
\hline Cronbach's Alpha & 0.796 & 0.748 & 0.805 & 0.755 & 0.823 & 0.079 \\
\hline
\end{tabular}

Source: developed by the authors

\section{Factor 1 - External Environment}

The first four variables in Table 1 comprise Factor 1. This factor was named External Environment. These variables presented proximity in their factorial loads, which were between 0.716 and 0.624 . Cronbach's Alpha achieved a reliability level of 0.796 . Highlighted among the characteristics of this factor relating to the enterprise's external environment (the macro-environment and the sector environment) are suppliers, purchasers, competition, and substitute products and services.

Entrepreneurs who reflect the variables related in Factor 1 tend to have a personal profile presenting flexibility in new situations, adapting easily to adversity. In dealing with these constant changes, the entrepreneurs acquire a dynamism created by the necessity to remain up-to-date in order to make insightful decisions, reflected by the proactiveness in the tasks to be executed.

The image of the enterprise is of utmost importance to relations with clients, suppliers, the community, and both internal and external collaborators.

\section{Factor 2 - Innovation}

The variables grouped in Factor 2, labeled Innovation, presented a Cronbach's Alpha of 0.748 . This factor groups the variables that present the entrepreneur as one who is always seeking innovative ideas and solutions to overcome obstacles during daily operations. As such, the entrepreneur does not flee from risks and challenges and considers the capacity to dodge blows much more important than careful planning. In this way, the entrepreneur takes advantage of this ability for innovation to keep one step ahead of the competition, thus establishing a competitive differential.

The variable "Love of Risks and Challenges" presented the lowest factorial load for Factor 2 (0.584). In other words, it possessed a less significant correlation. This could be evidence that risk and challenge are not necessarily present in the same context. The entrepreneur who loves facing challenges may not be disposed to taking risks.

Risk and autonomy are essential to let entrepreneurs tolerate error and failure. Employees need to know that their decisions may be made freely and that they will have a direct impact on their own 
work. They must make their decisions to arrive at the most effective solutions. The organization must allow them to make decisions about their own work processes, as well as avoid criticisms for wrong decisions.

\section{Factor 3 - Internal Environment}

Factor 3, labeled Internal Environment, consisted of variables with characteristics referring to the concern with and impact of the control, management, and organization of its tangible and intangible resources on the enterprise. It should be noted that all the variables grouped in this factor presented negative factorial loads, though they do not interfere negatively in the interpretation. The variable "Organization of Resources" was the one that presented the lowest factorial load (-0.369), which reflects its lower relevance with the internal environment factor. On the other hand, the variable "Performance Indicators" obtained a factorial load of 0.937. Therefore, economic factors influence internal strategic decisions for the enterprise in relation to its projections, budgets, obtainment of capital, investment, and performance in relation to growth in the country and the sector.

\section{Factor 4 - Experience}

Factor 4 was labeled Experience. It refers to the entrepreneur who has, as a principal differential, vast experience acquired before the decision to begin the enterprise. This fact is contingent for the good performance of the enterprise and provides security to believe in the entrepreneur's potential as a manager.

This is what Bernardi (2007) calls an "excellent technician": an entrepreneur who uses technical knowledge about some product or service (expertise) as the stimulus to initiate his or her own enterprise.

This scenario is reflected in the data acquired in this study, in which the variables "Previous Knowledge" and "Experience" presented high factorial loads (superior to 0.8 ).

\section{Factor 5 - Mission}

Factor 5 was labeled Mission and consisted of two factors. The "Mission of the Enterprise" was the variable that presented the greatest factorial load (0.954), or the best correlation between the original variables and the factors. The elevated Cronbach's Alpha (0.823) confirms the reliability of this Factor.

Enterprises with missions that are objective and clear achieve greater commitment from all who interact in the various processes of their businesses. It is through this instrument that the entrepreneur can clarify the objectives and values of the enterprise. Serra et al. (2004, p. 48) says that "the mission is the raisond'être of the organization."
The variable "Judicial and Governmental Knowledge" must be aligned with the company's mission, so that the objectives can be followed in a manner that is legal and ethical, respecting the questions related to social and environmental responsibility.

\section{Factor 6 - Impulsiveness}

Factor 6, and its variables, was labeled Impulsiveness. This factor stands out for providing a richer interpretation, as it is the only factor that contrasted the assertions with negative and positive factorial loads, which contributes to the importance of this study. We decided to name this factor as impulsiveness because of the contrast of the negative loads for the variables related to planning which can be interpreted as the opposite of impulsiveness, therefore more related to the factor load.

The entrepreneur who is characterized as impulsive certainly is not the one worried about detailed planning, who sees objectives both in the short and long term, or the one concerned with the level of employee commitment and recognizing the importance that they have to achieving the goals and objectives of the enterprise.

The impulsive entrepreneur can be compared to the entrepreneur described by Bhidé (2002), who believes that planning and analysis are only necessary when seen as useful, in addition to making subjective judgments in some cases. These entrepreneurs seek to save time and money that would otherwise be spent on studies of their ideas. They resist the temptation of an intensive investigation and trust in their own judgment.

Although the assertions do not present internal consistency (considering the Cronbach's Alpha = 0.079 ), they reflect a relevance to this analysis by contrasting the profile of the impulsive entrepreneur, who ignores the concern with planning, with the entrepreneur who rigorously follows the planned path and is unprepared to deal with the unexpected.

\section{INTEGRATED FACTORIAL ANALYSIS}

The relevance of analyzing the internal and external environments is shown by the important relationship and influence that these may exercise in the performance of the enterprise. They can contain the best practices of the market in the production of products/services. However, if the external factors are ignored, the life of the enterprise may be compromised if the products/services are not compatible with market needs. Julien (2010) states that the entrepreneur must learn how to manage, develop and analyze the resources according to the market expectation, through this, changes can be understood and information gathered in order to support the strategies, therefore, confirming the market needs attendance or create them. 
Analyses of the internal and external environments serve to verify if the mission of the enterprise - in respect to the intentions, ambitions and objectives that it hopes to achieve - are coherent with the external reality and exploit market opportunities. These characteristics contrast the variables composing the Impulsiveness Factor. There is a difference between entrepreneurs who follow their instincts and those who are guided by market practices and pre-established concepts, which are more analytical and cautious.

The impulsive entrepreneur is the one who prefers to resolve the unexpected in a fast manner, making instantaneous decisions. This could be related to the Innovation Factor, as this type of entrepreneur often tends to resolve situations in an innovative manner, in order to generate competitive differentials for the enterprise. The negative loads presented on the factorial analysis show that entrepreneurs are more willing to act by impulse rather than making plans. When discriminating the data, evidences were found that nascent entrepreneurs (with less than 2 years of experience in running businesses) represent the higher proportion of impulsive entrepreneurs.

A large percentage of entrepreneurs in the sample possessed previous knowledge or experience in the areas in which they constructed their enterprises. This clearly contributed to the entrepreneurs' conception of their enterprises, even if unconsciously, formulating strategic plans about the directives of the new projects.

All of these related characteristics are part of the life of entrepreneurs, who daily face difficulties and the unexpected in their enterprises. Thanks to these qualities, entrepreneurs are constantly honing their abilities to create and manage their own businesses and, over time, achieving success.

\section{CONCLUSION}

The Factorial Analysis grouped different characteristics of the sample. The negative loads of the impulsiveness factor shows a contradiction to the other factors, suggesting that there could be two profiles for entrepreneurs: the less strategic ones, represented primarily by the variables that compose the Impulsiveness Factor, and the more strategic ones, who are guided by detailed planning. This was explained by Sarasvathy (2001) through effectuation theory. During the early stages of the venture, the entrepreneur is normally constrained by lack of resources and need to develop his (her) business under the shadows of uncertainty.

Due to this, it is expected that entrepreneurs in nascent stages are more impulsive, taking opportunities that fit their existing resources and conditions rather than establishing a plan and going for it. According to effectuation theory, as the business grows and acquires more resources the same time it reduces uncertainty, the more objective oriented and less impulsive oriented the entrepreneur become (SARASVATHY, 2001). Possible viable ways to achieve better results can be easily foreseen when the entrepreneur increases his (her) maturity on the industry, resulting in better developed plans, with fewer risks and consequently more strategically developed, moving toward a causal model of thinking (SARASVATHY, 2001).

Nevertheless, as the data comprises businesses more than five years old, we should admit that mature entrepreneurs still take impulsive actions when running their business. On the other hand, although impulsiveness was found a key characteristic of entrepreneurs, it does not mean that entrepreneurs want to be impulsive. Most of them understand the negative aspects of taking decisions in the upfront of the business management dynamics. The lack of resources, time, knowledge and proper support that characterizes effectual model cannot freeze entrepreneurs' decisions about their ventures (SARASVATHY, 2001). This is the reason why strategy formulation is rare in nascent entrepreneurs, suggesting a possible research area for future studies, in other words, answering the question: Are nascent entrepreneurs as strategist than mature entrepreneurs?

The scenario changes along the time just like fog disappear on the entrepreneur pathway. With the experience and growing familiarity with the market and industry, the entrepreneur feel more confident to think about possible tracks for the business development as he gets more clear vision of this future. Considering the element of impulsiveness is an opposite factor for the act of planning, demonstrated into the data as the planning activities, we suggest the following proposition:

(P1) Entrepreneurial abilities influence the strategic planning of companies.

There are different levels of strategy. The instinctive level, often unconscious, presents no preoccupation with the formal preparation of documents for the dissemination and greater development of the idea to be put into practice, but which presents a coherent logic in regards to the action to be effected. The more strategic level presents minute analyses, documented and discussed by the entrepreneurs until a common ground is obtained, and then the plans are applied as a referential guide to achieve the goals.

This is why the domination of the external and internal environments is fundamental to the good performance of the business. Regarding the forces of the external environment, it is evident that the aspects of the macro-environment (political-legal, economic, social, and technological) and the industry (suppliers, purchasers, substitute products/services, potential entrants, and competition) influence the strategy formulation. The entrepreneur must be attentive to the changes to be unsurprised or even take advantage of the sudden opportunities that often arise in the market. 
The same way, it is clear that entrepreneurs perceive the importance of the forces of the internal environment. They are able to identify this scenario to detect possible strengths and weaknesses in their enterprises, as well as visualize the productivity of their resources, capacities, and competencies (PORTER, 2004). Finally, as the entrepreneur gets more information about internal and external environment, a direct consequence is the crescent alignment with the mission, vision, and objectives of the enterprise, consolidating the strategy formulation effort. Considering these findings we propose the following proposition:

(P2) Both internal and external environments influence the strategic planning of companies.

This study presents certain limitations. The literature related to the theme of entrepreneurship is still quite fragmented and presents connections with strategies that deserve amplification. Another limitation concerns the centralization of the sample. It focused on the Greater São Paulo region, which could have led to a result that is not applicable to the reality of other regions. Furthermore, there is the question of large-scale enterprises in the sample studied. As there were only a small number of large-scale enterprises included, there could be a bias in the results, as they are focused more on the profile of entrepreneurs with small- to medium-size companies.

As such, the authors suggest a continuation of this study with the following perspectives: 1) amplification of the nature of the sampled enterprises; 2) a survey of which personal characteristics could be determinants for the development of the enterprise; 3 ) Verify whether nascent entrepreneurs are more strategist or more impulsive than mature entrepreneurs; and 4) a study of the connection between the variables of Gartner (1998) and Mckenzie et al. (2007) with strategy as a guide for the initiation of entrepreneurial activities.

\section{REFERENCES}

Abebe, M.; Angriawan, A. Tran, H. (2010). Chief executive external network ties and environmental scanning activities: an empirical examination. Strategic Management Review, 4(1).

Analoui, F.; Karami, A. (2002). How chief executives' perception of the environment impacts on company performance. The Journal of Management Development, v. 21, n. 4, 290-305.

Antoncic, B.; Hisrich, R. D. (2003, Dez). Privatization, Corporate entrepreneurship and performance: Testing a normative model. Journal of Developmental Entrepreneurship, v.8 n.3, 197-218.

Bernardi, L. A. (2007). Manual de Empreendedorismo e Gestão: Fundamentos, Estratégias e Dinâmica. São Paulo: Atlas.
Bhidé, A. (2002). The Origin and Evolution of New Businesses. Oxford, Oxford University Press. 412 p.

Bhidé, A. (2004). As perguntas que todo empreendedor deve responder. In: Empreendedorismo e estratégia. Harvard Business Review. Rio de Janeiro: Campus.

Bird, B. (1988). Implementing entrepreneurial ideas: The case for intentions. Academy of Management Review, 13 (3), 442-454.

Bygrave, W.; Hofer, C. (1991). Theorizing about entrepreneurship. Entrepreneurship Theory \& Practice, n. 16, v. 2.

Bygrave, W.; Zacharakis, A. (2010). Entrepreneurship. Wiley: John Wiley \& Sons, Inc.

Daft, R. L.; Sormunen, J.; Parks, D. (1988). Chief executive scanning, environmental characteristics and company performance: an empirical study. Strategic Management Journal, v. 9, n. 2, Mar./Apr.

Eisenhardt, K.M. (1999). Strategy as strategic decision making. Sloan Management Review, 65-72, Spring.

Feuerschütte, S.G.; Godoi, C.K. (2007). Competências empreendedoras: um estudo historiográfico no setor hoteleiro. XXX Encontro Anpad., n.1.

Filion, L. J. (1991). Vision and Relations: Elements for an Entrepreneurial Metamodel. International Small Business Journal, v. 9, n. 2, 26-40.

Gartner, W. B. (1988). "Who is an entrepreneur?" Is the wrong question. American Journal of Small Business, v. 12, n. 4, $1-32$.

Global Entrepreneurship Monitor Annual Report. (2012). Empreendedorismo no Brasil. Relatorio Global, Parana, IBQP and SEBRAE.

Hair, J. F.; Anderson, R. E.; Tatham, R. L.; Black, W. C. (2006). Analise Multivariada de Dados. Porto Alegre: Bookman, 5th edition.

Hisrich, R. D.; Peters, M. P. (1986). Establishing a new business venture unit within a firm. Journal of Business Venturing, v.1, n.3, 307-322.

Hitt, M. A.; Ireland, R. D.; Hoskisson, R. E. (2005). Administração estratégica: competitividade e globalização. São Paulo: Pioneira Thomson Learning.

Ireland, R. D.; Covin, J. G.; Kuratko, D. F. (2009). Conceptualizing Corporate Entrepreneurship Strategy. Entrepreneurship: Theory \& Practice, Jan. 2009, vol. 33 Issue 1,1 9-46, 28p. 
Jain, S. C. (2000). Marketing planning and strategy. 6th edition. Cincinnati: South-Western College.

Julien, P. A. (2010). Empreendedorismo regional e economia do conhecimento. São Paulo: Editora Saraiva.

Karami, A.; Analoui, F.; Kakabadse, N. K . (2006). The CEOs' characteristics and their strategy development in the UK SME sector: An empirical study. The Journal of Management Development. Bradford: 2006. vol. 25, n. 3/4; 316.

Kickul, J.; Gundry, L. K.; Barbosa, S. D.; Whitcanack, L. (2009). Intuition Versus Analysis? Testing Differential Models of Cognitive Style on Entrepreneurial Self-Efficacy and the New Venture Creation Process. Entrepreneurship Theory and Practice, v. 33, Issue 2, 439-453, March.

Kirzner, I. (1973). Competition and Entrepreneurship. Chicago: University of Chicago Press.

Kumar, K.; Subramanian, R.; Strandholm, K. (2001). Competitive strategy, environmental scanning and performance: a context specific analysis of the relationship. International Journal of Commerce \& Management, v. 11, n. 1, 1-33.

Kuratko, D. F.; Hodgetts, R.M. (2008).Entrepreneurship: theory, process and practice. Sixth Edition, USA: Thomson.

Kuratko, D. F., Hornsby, J. S., Naffziger, D. W., Montagno, R.V. (1993). An Interactive Model of the Corporate Entrepreneurship Process. Entrepreneurship: Theory and Practice. v. 17, Issue 2.

Kuratko, D. F., Hornsby, J.S., Naffziger D. W., Montagno .R. V. (1993). Implement Entrepreneurial Thinking in Established Organizations. S.A.M. Advanced Management Journal. v.58, Issue 1.

Machado-Da-Silva, C. L., Cochia, C. B. R. (2003). Contexto ambiental, interpretação e estratégia em organizações: um estudo em pequenas empresas paranaenses. Encontro de Estudos em Estratégia (3Es) Conference proceedings, 1, Curitiba. Available at < http://www.anpad.org.br/3es/2003/dwn/3es200301.pdf $>$. Accessed in: Oct15 2004.

McClelland, D. (1961). Business Drive and National Achievement. Harvard Business Review, julyaugust, 99-112.
McKenzie, B.; Ugbah, S. D.; Smothers, N. (2007). "Who is an entrepreneur?" is it still the wrong question? Academy of Entrepreneurship Journal, v. 13 , n. $1,23-39$.

Mizumoto, F. M.; Artes, R.; Lazzarini, S. G.; Hashimoto, M.; Bede, M. A. A. (2010). Sobrevivência de empresas nascentes no estado de São Paulo: um estudo sobre capital humano, capital social e praticas gerencial. Revista de Administração da Universidade de São Paulo. São Paulo, SP, v. 45, n. 4, nov./dez.

Nassif, V. M. J.; Cerretto, C; Amaral, D. J.; Soares, M. T. R. (2007). Empreendedores sao Estrategistas? Um Estudo Exploratório da Ação de Empreendedores no Setor Alimentício da Cidade de São Paulo. Anais do III Encontro de Estudos em Estratégia. São Paulo.

Oliveira, D. P. R. (1991). Estratégia empresarial: uma abordagem empreendedora. São Paulo: Atlas, $2^{a}$ edition.

Pagnoncelli, D.; Vasconcellos F. P. (1992). Sucesso empresarial planejado. RJ: Qualitymark.

Porter, M. E. (2004). Estratégia Competitiva: Técnicas para Analises de Industrias e da Concorrência. Rio de Janeiro: Elsevier, $2^{\mathrm{a}}$ ed.

Quinn, J. B. (1980). Strategies for change: logical incrementalismo. Homewood: Irwin.

Sarasvathy, S. D. (2001). Causation and Effectuation: Toward a Theoretical Shift from Economic Inevitability to Entrepreneurial Contingency. The Academy of Management Review, v. 26, n. 2, 243 263.

Schuler, M. (2004). Management of the organizational image: a method for organizational image configuration. Corporate Reputation Review, v. 7, n. 1, 37-53, Spring.

Schumpeter, J. A. (1949). Economic theory and entrepreneurial history In: Change and the entrepreneur: postulates and patterns of Entrepreneurial history. Harvard University Press Cambridge-Mass.

Serra, F. A. R.; Torres, M. C. S.; Torres, A. P. (2004). Administração Estratégica: conceitos, roteiro pratico e casos. Rio de Janeiro: Reichmann; Affonso Editors.

Shane, S.;Venkataraman, S. (2004). The promise of entrepreneurship as a field of research, Academy of Management Review, v. 25, n. 1, 217-226. 
Shane, S.A. (2006). A General Theory of Entrepreneurship: The Individual-Opportunity Nexus. Northampton, MA: Edward Elgar.

Souza, E.C. L.; Guimarães, T.A. (2005). Empreendedorismo: além do plano de negocio. São Paulo: Atlas.

Subramanian, R.; Kumar, K.; Strandholm, K. (2009). The role of organizational competencies in the market-orientation-performance relationship: An empirical analysis. International Journal of Commerce \& Management. Bingley: v. 19, Issue 1.

Venkataraman, N. (1997). Strategic orientation of business enterprises: the construct, dimensionality and measurement. Management Science, v. 35, n. 8, 942-962, august.

Wright, P. L.; Kroll, M.J.; Parnell, J. (2000). Administração Estratégica: Conceitos. São Paulo: Atlas. 